\title{
The Impact of Applying Time Driven Activity-Based Costing on Improving the Efficiency of Performance in Jordanian Industrial Corporations: A Survey Study
}

\author{
Nabil Bashir Al-Halabi ${ }^{1} \&$ Yazan Mjahed Al-Mnadheh ${ }^{1}$ \\ ${ }^{1}$ Accounting Department, Faculty of Economics and Administration Sciences, Zarqa University, Jordan \\ Correspondence: Prof. Nabil Bashir Al-Halabi, Accounting Department, Zarqa University, Jordan. P.O. Box \\ 132222, Zarqa 13110, Jordan. Tel: 967-9739-0188. E-mail: alhalabi.fcs@gmail.com or nhalabi@zu.edu.jo; \\ manadha878@yahoo.com
}

Received: September 27, 2017

Accepted: October 12, $2017 \quad$ Online Published: October 30, 2017

doi:10.5539/ijef.v9n12p24

URL: https://doi.org/10.5539/ijef.v9n12p24

\begin{abstract}
The paper explored the impact of applying the time driven activity-based costing-TDABC- model (independent variables) on improving the efficiency of performance (dependent variables) in Jordanian industrial corporations. Based on a questionnaire form data from a sample of 73 participants at different managerial positions, from 30 industrial corporations listed in Amman stock exchange (ASE), were gathered and processed using the statistical package of social sciences. The main results showed that there are significant impacts of applying TDABC on improving the efficiency of performance in Jordanian industrial corporations. The main conclusion indicated that TDABC has the ability to benefit from technological developments on the basis of the activities' charts and reflected on pricing decision making processes in industrial corporations. The research also concluded that senior management and cost accountants of the sample studied did not desire in the short run to change the current cost accounting system due to the additional costs of using the new cost accounting system. The study recommended the application of TDABC in corporations where their operations relied on TDABC's constituents as proved its impact on reducing costs of products and increasing corporations profitability.
\end{abstract}

Keywords: time driven activity-based costing, performance efficiency, Jordanian corporations

\section{Introduction}

Enormous modern industrial developments and the widespread of international markets have led to increased competition among industrial companies, which necessitated the development of traditional costing systems to reduce production costs, in order to stay in the local market and expand their market shares in international markets (Judeh et al., 2011, p. 19; Huang, 2016, p. 18). In addition, ineffective use of performance evaluation measures led to difficulties in discovering ways to improve cost accounting systems that considered the core of success or failure of corporations (Whittington \& Delany, 2013, P. 77). In the area of cost accounting such external environmental developments accompanied and affected the development of cost accounting systems by which many cost tools have been adopted by corporations with the aim of achieving stability and continuity at work in line with changing environments (King, 2001, p. 27; Gorzen-Mitka \& Okreglicka, 2014, p. 3). Researchers pointed to many terminologies, such as, cost efficiency, accurate overhead cost assignments with the use of alternative coting tools, techniques and approaches to increase the performance efficiency and maximize the wealth of owners (Al-Halabi, 2013, p. 4; Krishnan, 2006, p. 6; Adkins, 2008, p. 3). Furthe, the optimal use of resources and the right timing of activities at work could reduce production costs, increase profitability, expand penetrattion the market, and reduce the product price (Al-Halabi, 2016, p. 55; Gorzen-Mitka \& Okreglicka, 2014, p. 231). Moreover, the importance of competitiveness proved to provide an appropriate competitive environment to achieve a greater efficiency in the resource allocation process and use it to encourage creativity, development and innovation that contribute to improving productivity, raising the quality and quantity of production, and improving profitability by reducing costs and prices (Abu-Saada, 2014; Moorthy, K., Yacob, 2013, p. 6). Although the activity based costing system is overcoming the problem associated with the traditional costing system by taking into account qualitative and quantitative cost drivers and differentiating between volume and non-volume based activities, it faced obstacles related to time consumed calculation and time estimation for units of time drivers based on timing of cost- effect criteria for different activities in corporations (Huang, 2016, p. 21; 
Gervais, Levant, \& Ducrocq, 2010, p. 8; Swenson \& Ansari, 2010, p. 14; Drury, 2006, p. 109). Other studies pointed to the successful application of TDABC and its effects on dividends policies adopted by industrial corporations and found a positive relationship between the application of TDABC and free cash flows and net cash flows from operating activities in industrial corporations (Abu- Ghiben, 2013, p. 35; Monroy, Nasiri, \& Pelaez, 2012, p. 15). It is also said that reducing production costs and controlling them is one of the most important issues for which the management is trying to make sound decisions (Garrison, Noreen, \& Brewer, 2012, p. 74; Bahr, 2016, p. 48).

Till now few studies explored the application of TDABC in industrial corporations where these studies called for more studies to apply TDABC in industrial corporations to which this research attempted to discover the impact of applying TDABC on the performance efficiency in the Jordanian context. The structure of this research consisted of four main parts: literature review, methodology of the research, results and interpretations, and conclusions and recommendations on the impact of applying the time driven activity-based costing (TDABC) the performance efficiency in the Jordanian industrial corporations.

\section{Literature Review}

The accounting literature referred to modern cost accounting approaches that can develop and update traditional cost accounting systems (Drury, 2006, p. 9; Ellis, 2003, p. 334; Rempel, 2015, p. 17; Horngren, Datar, \& Rajan, 2012, p. 56). The activity based costing system is proved to overcome the problem associated with the traditional costing system and its suitablility to complex environments and linked directly to the service for which activities were performed (Drury, 2004, p. 109; Horngren, Datar, \& Rajan, 2012, p. 221; Moorthy \& Yacob, 2013, p. 5). Further, pricing decisions became more flexible and relied on various optimal product mix which led the management to look for advanced cost approaches to improve performance and increase profitability of corporations (Rapp, 2010, p. 5; Gorzen-Mitka, \& Okreglicka, 2014, p. 5). In the cost accounting context Kaplan $\&$ Anderson referred to steps for applying the system of time driven activity-based costing (TDABC) through: (i) identification of the estimated cost unit, where more than $20 \%$ of the employees', workers' and machines' works were spent in activities such as work arrivals and departures and machines maintenance, outside their effective productive capacity to which only around $85 \%$ of the company's operational capacity, at a large extent, is usually estimated; (ii) estimation of the time unit, where this is the core for TDABC application, thus machines are worked based on marketing, production and purchases orders; (iii) determination of the time equations, which is equal to the total time of all activities participating in producing the required product/s (Kaplan \& Anderson, 2007, p. 12). This is illustrated earlier in the following TDABC equation (Kaplan \& Anderson, 2003):

$$
T=\mathrm{bo}+\mathrm{b} 1 . X 1+\mathrm{b} 2 . X 2+\mathrm{b} 3 . X 3+\ldots \ldots \ldots+\mathrm{b} . X n
$$

where:

$\mathrm{T}=$ total time required to fulfill the activity;

bo = A fixed magnitude of the activity's time;

b1 = time consumed for one unit of the first time driver;

$\mathrm{X} 1=$ the time driver for the first activity;

$\mathrm{X} 2$ = time driver for the second activity;

$\mathrm{Xn}=$ time driver for activity $\mathrm{n}$;

$\mathrm{n}=$ the number that is causing the time.

Advocates of the use of TDABC model in industrial corporations pointed to the importance of calculating time drivers rates to find out the cost of an activity and addressed its effective outputs emerged from its application (Huang, 2016, p. 29). The TDABC is characterized by ease and speed in use, through identification of the cost of the unit and the time required for an activity operation (Kaplan \& Anderson, 2007, p. 41; Huang, 2016, p. 31). Other studies identified similarities and differences between ABC and TDABC and found the ability of TDABC in reducing costs and upgrading the quality of services of activities in corporations, which is an indication of the necessity of establishing the activities' charts as an important requisite to apply the TDABC model (Rozotocki, 2010, p. 7; Rempel, 2015, p. 21; Monroy, Nasiri, \&Pelaez, 2012, p. 16).

In response to the need to develop cost hierarchies, the cost system has emerged on the system time driven activity based costing (TDABC), which gives companies the practical option to determine cost utilization and provides special operational capabilities such as orders, products and key customers profitability (Monroy, Nasiri, \& Pelaez, 2012, p. 18). Moreover, the application of the time driven activity-based costing has several accumulated advantages for corporations through improving the effective operation of cost systems; enabling 
cost managers to discover areas of profitability center managers to obtain accurate information to prioritize process improvements; rationalizing the product diversity or products integration, as well as customer price orders (Al-Halabi, 2016, p. 57; Bahr, 2016, p. 51; Huang, 2016, p. 58). Further, senior and middle managers could adopt up-to-date cost techniques to tackle unexpected operational efficiency and to take sound pricing decisions in different activities of corporations (Dutta \& Gigler, 2002, p. 15; Monroy, Nasiri, \& Pelaez, 2012, p. 21). Besides, limited studies pointed to the role of costing systems based on time driven activities to strengthen relationships between TDABC and related variables, such as pricing decisions, efficiency and effectiveness, cost benefit analysis, profitability and competitiveness where the applicationad and intehrations between them can provide benefits to all parties interested in corporations (Kaplan \& Anderson 2007, p. 15; Rapp, 2010; Al-Halabi, 2016, p. 55; Hilton, 2008, p. 231; Lin, 2012, p. 14).

This research is in line with the aforementioned discussions aiming to explore the impact of applying the time activity-based costing (TDABC) on improving the efficiency of performance in Jordanian industrial corporations listed in Amman stock exchange (ASE).

\section{Methodology of Research}

The research methodology relied on a descriptive and analytical approach using the questionnaire forms to collect the data required and achieve its objectives based on: research problem, research hypotheses, research method, limitations of research, and procedural definitions.

\subsection{Research Problem}

The increasing competition in the market for industrial companies put the management and decision-makers under pressure by looking for ways to make internal operations more competitive in dynamic and complex environments and to maintain the continuity of the corporation in appropriate decision-making processes. The application of time driven activity-based costing (TDABC) as a modern cost approach can improve the performance efficiency of corporations and secure the continuity of these corporations within the Jordanian economy. Hence, the problem of the study represented to answer the following main and sub-main questions:

Q1. What is the impact of applying the time driven activity-based costing (TDABC) (activities charts, quantitative time drivers and qualitative time drivers) on improving the efficiency of performance (reducing costs and increasing profitability) in Jordanian industrial corporations listed in Amman Stock Exchange?

Q1.1 What is the impact of applying the time driven activity based costing (TDABC) (activities charts, quantitative time drivers and qualitative time drivers) on reducing costs in Jordanian industrial corporations listed in Amman Stock Exchange?

Q1.2 What is the impact of applying the time driven activity based costing (TDABC) on increasing profitability in Jordanian industrial corporations listed in Amman Stock Exchange?

The research provided a survey analysis on the impact of applying the time driven activity-based costing (TDABC) on improving the performance efficiency in activities of Jordanian industrial corporations, as shown in Figure 1.

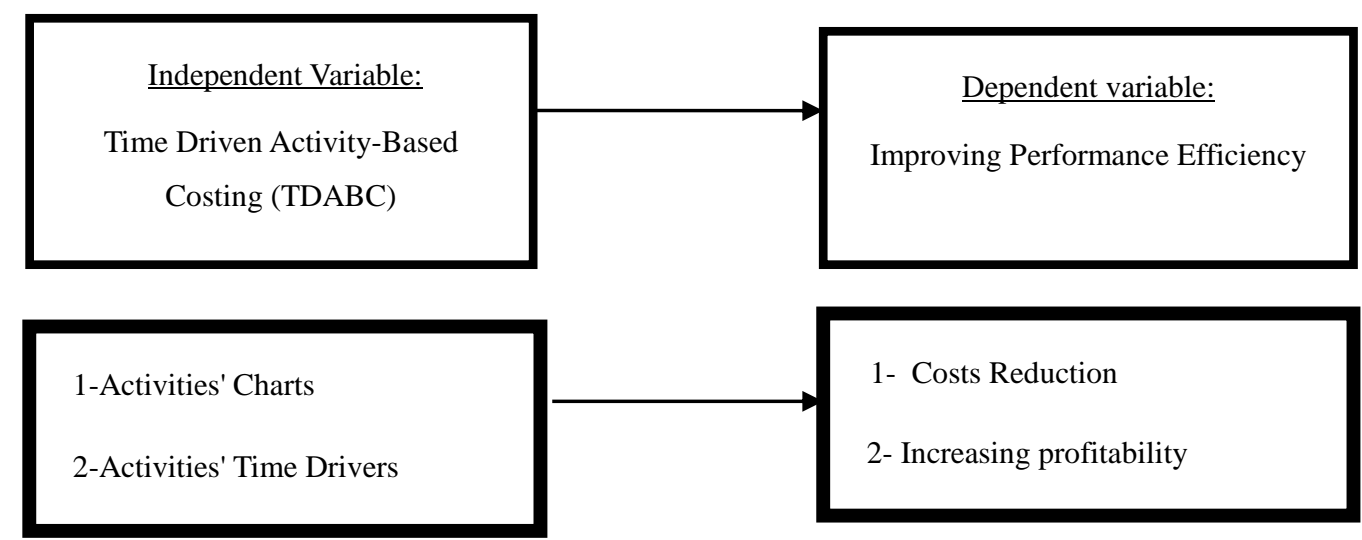

Figure 1. Research framework

Source: Prepared by researchers based on (Gervais, Levant, \& Ducrocq, 2010, p. 11; Monroy, Nasiri, \& Pelaez, 2012, p. 12; Garrison, Noreen, \& Brewer, 2012, p. 87). 


\subsection{Research Hypotheses}

The research presented the following hypotheses:

HO1: There is no significant impact ( $\alpha \leq 0.05$ ) of applying the impact of applying the time driven activity-based costing (TDABC) (activities charts, quantitative and qualitative time drivers) on improving the efficiency of performance (reducing costs and increasing profitability) in Jordanian industrial corporations listed in Amman Stock Exchange?

HO1-1: There is no significant impact ( $\alpha \leq 0.05$ ) of applying the impact of applying system time driven activity based costing (TDABC) (activities charts, quantitative and qualitative time drivers) on reducing costs in Jordanian industrial corporations listed in Amman Stock Exchange?

HO1-2: There is no significant impact ( $\alpha \leq 0.05)$ of applying the time driven activity based costing (TDABC) on increasing profitability in Jordanian industrial corporations listed in Amman Stock Exchange?

\subsection{The Research Method}

The research method represented the research sample of 30 (out of 67) Jordanian corporations listed in Amman stock exchange (ASE) that were chosen randomly according to the information published on the Securities and Exchange Commission Center, which was absorbed on 18/4-2017. Data gathered from the output of 73 questionnaire forms (out of 87) which were distributed to participants of managers, namely: general managers, financial, production, sales managers and cost Accountants who hold positions at the top and middle management of the selected sample. The valid questionnaires were processed and analyzed based on a Likert five-points scale through the application of the SPSS program. The research participants and levels of responses shown in Table 1.

Table 1. Distribution of the research sample and percentage of response

\begin{tabular}{lccc}
\hline Participants distribution & Middle Level Mangament & Top Management & Total \\
\hline 1- General Managers & -- & 17 & 17 \\
2- Planning, purchasing, selling, financing, controlling, cost & 26 & -- & 26 \\
accounting, and warehousing. & & & -- \\
3- Accountants and cost accountants & 44 & 17 & 44 \\
Total & 70 & 16 & 87 \\
Responses & 57 & $94 \%$ & $84 \%$ \\
$\%$ of responses & $81 \%$ & & 73 \\
\hline
\end{tabular}

\subsection{Limitations of the Research}

The following research difficulties in collecting and organizing the data required to answer the research questions and testing its hypotheses, despite using interviews techniques:

1) A number of participants had to be followed in order to complete the questionnaires, and researchers were under pressure several times to guarantee completeness of the questionnaire forms.

2) Some participants needed more clarification in the process of completing the questionnaire and others were lacking subject specialization so we had decided to omit six questionnaire forms.

3) Limited access to participants' works and some of them had no experience at work leading to disregard seven questionnaire forms.

\subsection{Procedural Definitions}

1). Time Driven Activity-Based Cost (TDABC): An updated system for both traditional and activity-based systems. It is a modern cost assignment approach or system used by corporations that relied on its constituents in terms of the identification of the estimated cost unit, the estimation of the time unit, and determination of the time equations arriving at the average cost of resources and the time required to carry out an activity. The TDABC uses different quantitative and qualitative time drivers in corporations (Brimson, 2001, p. 78; King, 2001, p. 26; Monroy, Nasiri, \& Pelaez, 2012, p. 8).

2). Activities' Charts: A list of different main and support activities each of which uses resources in terms of materials and equipment, where the management responsibility is to find out which activities are added value and compared with non-valued added activities in Jordanian industrial corporations (Garrison, Noreen, \& Brewer, 2012, p. 68). 
3). Activities' Time Drivers: There are two types of time drivers in corporations, namely, measurable qualitative time drivers such as no. of direct machine hours; and measurable qualitative time drivers, such as no. of purchasing orders processed or times of setting up machines (Kaplan \& Anderson, 2003, p. 36).

4). Performance Efficiency: It is the dependent variable of this study that is represented by two elements: increased profitability and cost reduction and the management responsibility to improve the corporation's efficiency in the competitive environment (Adkins, 2008, p. 4).

5). Cost Reduction: It is an element of performance efficiency to which management can achieve by applying modern cost tools, and attempts made to integrate between them to update current performance measures and decision-making processes (Hilton, 2008, p. 231; Horngren, Datar, \& Rajan, 2012, p. 218).

6). Profitability: It is a company's ability to generate profits and can be defined as the net cash flow resulting from the coprporation investments (Gibson, 2017, p. 325).

\section{Results and Interpretations}

An introduction and clarification were made in the questionnaire form on two elements of the time driven activity-based costing (TDABC) and their linkage with the two elements of the performance efficiency in order to discover areas of cost reduction and increasing profitability of main activities of 30 selected Jordanian industrial corporations. The Cronbach-Alpha test was run to find out the consistency and stability of the questionnaire items. It was found that the percentage reached in total more than $92 \%$, which means that all questions and items of the questionnaire forms are highly consistent (Sekaran \& Bougie, 2010, p. 311), as shown in Table 2.

Table 2. Results of the consistency and stability of the questionnaire elements

\begin{tabular}{lc}
\hline Research Variables & Cronbach-Alpha \\
\hline All questions & $79 \%$ \\
Application of the TDABC & $61 \%$ \\
Performance Efficiency & $76 \%$ \\
\hline
\end{tabular}

Before testing research hypotheses an ordinal scale on the output of the questionnaires has been adopted . The interpretation of the arithmetic averages for the estimation of sampling units on each paragraph of the questionnaire were based on the following equation (Sekaran \& Bougie, 2010, p. 311):

The length of the category $=$ the upper limit (5) - the minimum (1) $/$ the number of categories (3) $=(5-1) 3 /=3 / 4=$ 1.33. The results shown in Tanle 3 .

Table 3. The statistical arithmetic averages, standard deviations and relative importance of applying TDABC in Jordanian industrial corporations

\begin{tabular}{lccc}
\hline Research variables based on the questionnaire items & Arithmetic Mean & Standard Deviation & Relative importance \\
\hline Application of TDABC & 3.73 & 0.67 & High \\
Cost Reduction & 3.79 & 0.61 & High \\
Increasing profitability & 3.89 & 0.71 & High \\
\hline
\end{tabular}

\subsection{Results of Main Hypothesis HO-1}

The null hypothesis stated that there is no impact of applying the time driven activity-based costing (TDABC) on improving the efficiency of performance of Jordanian industrial corporations, results of regressions were shown in Table 4.

Table 4. Regression results on applying TDABC on improving the efficiency of performance

\begin{tabular}{lcccc}
\hline Sig. (2-tailed) & DF & Av. Use $\%$ & T & H0-1 \\
\hline .000 & 72 & $75 \%$ & 4.320 & Rejected \\
\hline
\end{tabular}

Based on the results of Table 4 and the interviews techniques, there were benefits from the application of TDABC, and its ability to help management to see the whole picture of activities' performance, evaluate the competitive strategy of the company, and improve pricing decisions for different products. Moreover, the sample 
of industrial corporations were applying the TDABC differently (Average use $=75 \%$ ) and accordingly Ho- 1 is rejected, in that there is a significant impact of applying TDABC (consisted of two elements) on improving the efficiency of performance (consisted of two elements) in industrial corporations in Jordan $(\mathrm{T}=4.320$, and sig. $=$ 0.000). This result is in line with the study by Tse, 2014, p. 152; Kasasbeh, 2014, p. 25).

\subsubsection{Results of Sub-Main Hypothesis HO1-1}

The null hypothesis stated that there is no impact of applying the time driven activity-based costing (TDABC) on reducing costs of activities of Jordanian industrial corporations, as shown in Table 5.

Table 5. Regression results on applying TDABC on reducing costs

\begin{tabular}{lcccc}
\hline Sig. (2-tailed) & DF & Av. Use $\%$ & T & H0-1-1 \\
\hline .000 & 72 & $76 \%$ & 2.74 & Rejected \\
\hline
\end{tabular}

The study found difficulties associated with the application of TDABC in industrial corporations, as follows: (i) weak cooperation between activities with conflicting procedures and steps of the TDABC application; (ii) underestimation of overhead costs among main activities for pricing decisions making processes; and (iii) unqualified employees who can apply the TDABC in industrial corporations. Accordingly, Table 5 showed the regression results of the sub-main hypothesis, thus, the H0-1-1 is rejected in that there is significant impact ( $\alpha \leq$ $0.05)$ of applying TDABC on reducing costs in industrial corporations in Jordan $(\mathrm{T}=2.74$ and sig. $=0.000)$. This result is in line with the study by Rempel (2015, p. 25).

\subsubsection{Results of Sub-Main Hypothesis HO1-2}

The null hypothesis stated that there is no impact of applying the time driven activity-based costing (TDABC) on increasing profitability of Jordanian industrial corporations, as shown in Table 6.

Table 6. Regression results on applying TDABC on increasing profitability

\begin{tabular}{lcccc}
\hline Sig. (2-tailed) & DF & Av. Use $\%$ & T & H0-1-2 \\
\hline .000 & 72 & $78 \%$ & 2.92 & Rejected \\
\hline
\end{tabular}

Participants emphasized that there was a need to adopt training programs and management participation to face competition in the local market if the corporation is to be profitable, thus, well qualified and trained people at work in different activities were urgently needed in order to achieve performance efficiency at all level of activities in corporations. Accordingly, Table 6 showed the regression results of the sub-main hypothesis, where H0-1-2 is rejected, in that there is significant impact $(\alpha \leq 0.05)$ of applying the TDABC on increasing profitability in industrial corporations in Jordan $(\mathrm{T}=2.92$, and sig. $=0.000)$. This result is in line with the study by Monroy, Nasiri, and Pelaez (2012, p. 22).

\section{Conclusions and Recommendations}

\subsection{Conclusions}

There are a number of conclusions emerged from the aforementioned results that showed the positive impact of applying the TDABC in Jordanian industrial corporations:

1) Based on the descriptive statistical analysis participants perceived the extent of applying TDABC is $74.6 \%$ with high relative importance of this model in these corporations. The conclusion is that there are differences in applying TDABC between these corporations.

2) Based on the inferential statistical analysis there were significant impacts of applying TDABC on improving the efficiency of performance in Jordanian industrial corporations (sig.= 0.000). The conclusion indicated that TDABC has the ability to benefit from technological developments on the basis of the activities' charts as reflected on pricing decision making processes in corporations. It is also concluded that the management of these corporations was interested in applying TDABC, despite difficulties associated with the full application of this technique in all activities of corporations.

3) As for the effect on reducing costs in corporations results indicated significant impacts of applying TDABC on reducing costs in Jordanian industrial corporations (sig. $=0.000$ ). The conclusion is that senior management and cost accountants of the sample studied did not desire in the short run to change the current cost accounting 
system due to the additional costs of using the new cost accounting system.

4) In respect of the effect on increasing profitability in corporations results pointed to significant impacts of applying TDABC on increasing profitability in Jordanian industrial corporations (sig.=0.000). The conclusion is that there are conditions for the successful application of TDABC which could lead to increase profitability compared with the nonuse of TDABC in these corporations.

\subsection{Recommendations}

The research recommendations are as follows :

1). Full application of TDABC in Jordanian corporations is required as proved its impact on improving the efficiency of performance in terms of cost reduction and increasing profitability through the activities' charts of industrial corporations.

2). Continuous studies on the importance of TDABC and its integration with other modern cost tools such as balanced-score cards for both corporations and individuals with the aim of enhancing the performance efficiency of activities' charts based on the findings of this research.

\section{Acknowledgments}

We gratefully acknowledge helpful assistance from the management of industrial corporations; and comments from our colleagues in the accounting department- Zarqa University, Jordan.

\section{References}

Abu-Ghiben, H. (2013). Time Driven Based Costing System (TDABC) and its Impact on the Dividend Distribution Policy of Public Shareholding Companies Listed on the Palestine Stock Exchange. Unpublished Master Thesis, Al-Azhar University - Palestine, pp. 15-45.

Abu-Saada, O., \& Daida, A. (2014). Requirements for Achieving Competitiveness in Egyptian Universities: A Case Study on Mansoura University. Journal of the Faculty of Education in Banha, 25(10), 77-107.

Adkins, T. (2008). Five Myths about Time-Driven Activity-Based Costing. Sascom Magazine, 1-5.

Al-Halabi, N. (2013). The Role of Management Control and Accounting Systems in Increasing the of Activities of Industrial Companies. The International Institute for Science, Technology and Education (IISTE). European Journal of Business and Management, 5(13), 147-158.

Al-Halabi, N. (2016). The Impact of Applying Balanced Scorecards on Increasing the operational Efficiency of Activities in Industrial Companies. Journal of Innovative Systems Design and Engineering, 7(7), 53-63.

Al-Kasabeh, A. (2014). Factors Affecting the Application of Cost Accounting on Time-Based Activities in Commercial Banks Operating in Jordan (An Exploratory Study). Unpublished Master Thesis, Amman Arab University, Jordan.

Bahr, W. (2016). Radio Frequency Identification and Time-Driven Activity Based Costing: RFID-TDABC (pp. 15-62). PhD Dissertation, Aston University.

Brimson, J. (2001). Activity Accounting : An Activity-Based Costing Approac (2nd ed., p. 182). New York, John Wiley.

Drury, C. (2006). Management Accounting For Busines (6th ed., p. 9). Bath, Patrick Bond, UK.

Dutta, S., \& Gigler, F. (2002). The Effect of Earning Forecasts on Earnings Management. Journal of Accounting Research, 40(3). https://doi.org/10.1111/1475-679X.00065

Ellis, N. J. (2003). Activity Based Costing in User Services of an Academic Library. Library Trends, 51(3), 334-348.

Garrison, R., Noreen, E., \& Brewer, P. (2012). Managerial Accounting (15th ed.). McGraw-Hill//rwin. A Business Unit of the McGraw-Hill Companies Inc. 1221 Avenue of the Americas, New York.

Gervais, M., Levant, Y., \& Ducrocq, C. (2010). Time-Driven Activity-Based Costing (TDABC): An Initial Appraisal through a Longitudinal Case Study. Retrieved from https://www.researchgate.net/publication/49134224

Gibson, H. (2017). Financial Reporting and Analysis Using Financial Accounting Information (15th ed., pp. 255-461).

Gorzen-Mitka, I., \& Okreglicka, M. ( 2014). Improving Decision Making in Complexity Environment. Procedia Economics and Finance, 5. https://doi.org/10.1016/S2212-5671(14)00819-3 
Hilton, R. (2008). Management Accounting-Creating Value in A Dynamic Business environment (pp. 230-232). McGraw-Hill Publications, USA.

Horngren, C., Datar, S., \& Rajan, M. (2012). Cost Accounting: A Managerial Emphasis (14th ed.). Prentice-Hall International, New Jersey.

Huang, Y. T. (2016). Evaluation and Recommendation of Implementing Time-Driven Activity-Based Costing in Health Care. PhD Dissertation, The University of Texas. School of Public Health, Houston, Texas, pp. 3-65.

Judeh, A., M., Nimer, M., K., \& Khrisatt, U. (2011). The Extent of Using Management Accounting Approaches in Jordanian Manufacturing Listed Companies- A Survey Study. Economic and Management Journal, 1(37), 13-37.

Kaplan, R., \& Anderson, S. (2003). Time-Driven Activity Based Costing. Harvard Business Review. Retrieved from https://ssrn.com/abstract=485443

Kaplan, R., \& Anderson, S. (2007). Time-Driven Activity-Based Costing. Harvard Business School Press.

King, A. (2001). The Current Status of Activity Based Costing Management Accounting (2nd ed., pp. 24-30). Thomson Learning.

Krishnan, N. (2006). An Application of Activity Based Costing in Higher Learning - Institution: A Local Case Study. Contemporary Management Research, 2(2), 16.

Lin, W. C. (2012). Financial Performance and Customer Service: An Examination Using Activity-Based Costing of 38 International Airlines. Journal of Air Transport Management, 19, 13-15. https://doi.org/10.1016/j.jairtraman.2011.12.002

MAS. (2002). Target Cost, The society of Management Accounts of Canada. Canada.

Monroy, C., Nasiri, A., \& Pelaez, M. (2012). Activity Based Costing, Time-Driven Activity Based Costing and Lean Accounting Differences among Three Accounting Systems' Approach toManufacturing. $6^{\text {th }}$ International Conference on Industrial Engineering and Industrial Management. XVI Congerso de Industrial de Organization.

Moorthy, K., \& Yacob, P. (2013). Green Accounting: Cost Measures. Open Journal of Accounting, 1-17.

Rapp, M. S. (2010). Information Asymmetries and the Value-Relevance of Cash Flow and Accounting FiguresEmpirical Analysis and Implications for Managerial Accounting. Center for Entrepreneurial and Financial Studies (CEFS), TUM Business School- Technische Universitat Munchen, pp. 1-25.

Rempel, M. (2015). A Time-Driven Approach to Capability Costing. Sa Majesté la Reine (En Droit Du Canada). DRDC-RDDC-2015-R179. Telle que réprésentée par le ministre de la Défense nationale, pp. 2-28.

Rozotocki, N. (2010). Activity-Based Management for Electronic Commerce: A Structured Implementation Procedure. Journal of Theoretical and Applied Electronic Commerce Research, 5(1), 1-10. https://doi.org/10.4067/S0718-18762010000100002

Sekaran, U., \& Bougie, R. (2010). Research Methods for Business: A Skill-Building Approach (5th ed., p. 311). New York: John Wiley and Sons Inc.

Swenson, D., \& Ansari. (2010). Best Practices in Target Costing. Management Accounting, 2(1), 12-15.

Tse, M., \& S., C. (2014). Time-Driven Activity-Based Costing Model: A Note. Taiwan Institute of Business Administration. Business Management Review, 10(3), 147-155.

Whittington, R., \& Delany, P. (2013). Wiley CPA Examination Review: Outlines \& Study Guide (39th ed., p. 77). John Wiley \& Sons Inc.

\section{Copyrights}

Copyright for this article is retained by the author(s), with first publication rights granted to the journal.

This is an open-access article distributed under the terms and conditions of the Creative Commons Attribution license (http://creativecommons.org/licenses/by/4.0/). 